\title{
ДУХОВНІСТЬ І МОРАЛЬ ЛІКАРЯ В УМОВАХ ПАНДЕМІї
}

\section{Котелюх М. Ю.}

докторантка кафедри внутрішньої медицини № 2, клінічної імунології та алергології ім. Л. Т. Малої, Харківський національний медичний університет, м. Харків, Україна

У статті розкрито роль духовності й моралі у виконанні професійної діяльності лікаря. Заначено, щзо умови пандемї змінили ставлення людини до себе, здоров'я родичів, стосунків з іншими людьми. Пріоритетними стали почуття самозбереження й відповідальності за життя іншої людини.

Ключові слова: здоров'я, лікарі, етичний кодекс, толерантність, mурбота.

The article reveals the role of spirituality and morality in performing the professional activity of a doctor. It is noted that the conditions of the pandemic have changed a person's attitude to himself, the health of relatives, relationships with other people. A sense of self-preservation and responsibility for another person's life became a priority.

Key words: health, doctors, code of ethics, tolerance, care.

Нині людство опинилося в тупиковій ситуації. Високий рівень розвитку технологічних процесів у різних сферах науки і техніки, поширення мережі інформаційно-комунікаційних технологій і заповнення ними освітнього простору свідчать про те, що людство розвивається, планетарне мислення набирає обертів. Однак, пандемія covid захворювання показала, що існують проблеми, з якими людству важко справитися.

Особливої уваги заслуговують лікарі, оскільки вони беруть на себе відповідальність за якісне обстеження й лікування пацієнтів, зокрема й в умовах пандемії. Умови карантину, як одностайно зауважують дослідники [1], змінили ставлення людини до власного здоров'я, активізували потреби розуміння іншої людини, турботи за їі психічний і фізичний стан під час пандемії. Духовність і мораль $є$ ціннісними орієнтирами поведінки й професійної діяльності лікарів, побудови взаємин з пацієнтами та їхніми родичами, співпраці з колегами на міжнародному рівні.

Мета статті - розкрити роль духовності й моралі лікаря в умовах пандемії. 
Розділ І. Ціннісні орієнтири духовно-інтелектуального виховання, розвиток духовно-інтелектуальних якостей особистості в умовах співпраці й інклюзії

Духовність лікаря не є штучно описаною. Кожен день лікар зустрічається $з$ пацієнтами, котрі розгублені, знервовані, невпевнені, а потреби виживання в умовах пандемії $є$ найбільш повними й усвідомленими. Обумовлено це тим, що в реальному житті гинуть люди від такого захворювання, страждають родини, близькі. Уцілому знищується генофонд країни, оскільки вмирають не лише люди похилого віку, але й молоді люди. У певній мірі лікар є «духовником» пацієнтів, оскільки критичні ситуації має переживати разом із хворим і його близькими, співчувати, співпереживати.

Як зазначено в Етичному кодексі лікаря [2], він має гуманно ставитися до людини незалежно від іiі приналежності до нації, віри сповідання, культури виховання. Характерними рисами лікаря є благодійність і милосердя, порядність і справедливість, толерантність і відповідальність. По суті ми називаємо категорії моралі та всі вони заслуговують на схвалення, адже завдяки таким рисам лікар зберігає й захищає життя і здоров'я людини, бере участь у реабілітації здоров'я людини після захворювання.

Виникають дискусії на основі реальних фактів. Так, в Україні з 11 по 17 жовтня 2021 року було госпіталізовано з коронавірусною хворобою 27488 людей, з яких 25893 осіб (94,2\%) не отримали жодної дози антиковідної вакцини [3]. Праця лікаря стала безпечною та ризикованою. Як відомо, відбувається відтік кадрів з медичної сфери. Пояснюється це нестабільним заробітком лікаря, незабезпеченістю з боку держави, негативним ставленням певної частки населення, котра звинувачує лікаря в усіх «бідах», що звалилися на людину. За таких обставин моральні якості (добро, совість, обов'язок, щастя, чесність і благородство) допомагають лікареві здійснювати професійну самореалізацію, розкривати творчий потенціал, виконувати обрану місію життя - спасати життя людини. У спасінні життя людини вбачаємо головний сенс духовності й моралі лікаря.

Дискусійним є питання стосовно вакцинування, що охоплює населення не лише нашої країни. Учена Б. Островська [4] нагадує про дотримання біоетичних принципів під час масової вакцинації населення. Учена вважає, що в ситуації пандемії необхідно: виявляти повагу й визнавати права людини під час організації вакцинування населення; надавати пріоритет потребам і здоров'ю людини над пріоритетами суспільства і науки; уникати й запобігати ризикам для життя людини; 
не порушувати автономію й цілісність особистості в разі втручання у фізичну й психологічну сферу життя.

Отже, у виконанні професійної діяльності лікаря важливу роль відіграють духовність і мораль. Умови пандемії змінили ставлення людини до себе, здоров'я родичів, стосунків з іншими людьми. Пріоритетними стали почуття самозбереження й відповідальності за життя іншої людини.

\section{Список використаних джерел:}

1. Досвід переживання пандемії covid-19: дистанційні психологічні дослідження, дистанційна психологічна підтримка: матеріали онлайн-семінарів 23 квітня 2020 року «Досвід карантину: дистанційна психологічна допомога і підтримка» та 15 травня 2020 року «Дистанційні психологічні дослідження в умовах пандемії covid-19 і карантину» / [за наук. ред. М.М. Слюсаревського, Л.А. Найдьонової, О.Л. Вознесенської]. Київ : ІСПП НАПН України, 2020. [електронне видання]. 121 с.

2. Етичний кодекс лікаря (2019). Режим доступу: https://zakon.rada.gov.ua/ rada/show/n0001748-09\#Техt (Дата звернення: 10.09.2021).

3. Країна задихається: пандемія, якої можна було уникнути. Режим доступу: https://www.unicef.org/ukraine/stories/suffocating-country (Дата звернення: 19.10.2021).

4. Островська Б. В. Вакцинація проти COVID-19 в Україні: чи дотримані біоетичні стандарти захисту прав людини. Здоров'я, медицина та філософія: стратегічні виживання. Матеріали IX Міжнародного симпозіуму з біоетики (15-16 квітня 2021, м. Київ) / упоряд. С. В. Пустовіт, Б. І. Остапенко. Київ : Графіка і дизайн, 2021. С. 56 - 57. 